\title{
Viability of Microorganisms in The Conditions of Permafrost
}

\author{
Neustroev MP ${ }^{1,2 *}$, Tarabukina NP $^{1}$ and Stepanova AM $^{1}$ \\ ${ }^{1}$ Laboratorie of Veterinary Biotechnology, FSBIS FRC YSC SB RAS, Yakut Scientific Research Institute of Agriculture named after Safronov M.G, Russia \\ ${ }^{2}$ FSEI HPE, Yakut State Academy of Agriculture, Russia
}

*Corresponding author: Neustroev MP, Laboratorie of Veterinary Biotechnology, FSBIS FRC YSC SB RAS, Yakut Scientific Research Institute of Agriculture named after Safronov M.G, Yakutsk, Russia.

Received Date: June 24, 2019

Published Date: July 01, 2019

\section{MIni Review}

The generally accepted warming of the climate in the Arctic may increase the risk of the emergence and spread of infectious diseases of humans and animals due to the melting of permafrost, the intensive development of natural resources, controlled and uncontrolled paleontological excavations, expansion of vector habitats (insects, rodents), changes in the migration routes of migratory birds.

It is very important to know the survival time of microorganisms in the environment for the sanitary-bacteriological assessment of environmental objects, as well as determining the possible period of contamination by their pathogenic and conditionally pathogenic microflora in case that they are released by sick animals or bacteria carriers.

The studies carried out in the YSRIA showed that the survival time of some microorganisms at environmental objects in permafrost conditions is 2-3 times longer than the survival time of similar microorganisms in the southern and European territories of Russia and abroad. According to the results of our research, in the livestock buildings, E. coli and Staphylococcus aureus survive 90180 days, and the causative agent of trichophytosis remains viable and pathogenic for more than 2 years (observation period). In manure E. coli, the horse strangles streptococcus, Staphylococcus aureus survive from 1.5 to 2 years, and Mycobacterium tuberculosis to 4 years. In the surface layers of permafrost soils, coccal forms of bacteria (in summer) survive up to several months, the causative agents of salmonellosis remain viable and pathogenic for more than 1 year, and the causative agents of tuberculosis, depending on the type of mycobacteria and depth, survive from 1 to 3 years. Thus, permafrost contributes to the long-term preservation of foci and factors of transmission of infections.
The scientists of the YSRIA established a significant amount of aerobic spore-forming bacteria (more than 2x106 CFU/g) in the frozen soils of Central Yakutia in the study of microbial contamination, the survival time of microorganisms. Aerobic spore-forming bacteria are widely distributed in the natural environment of Yakutia and, apparently, played a large role in various biological processes due to their ability to form spores and high adaptive capabilities. We studied the biological properties of spore bacteria isolated from permafrost soils and established their high antagonistic activity against pathogenic and conditionally pathogenic microorganisms for humans, animals, and plants. Two strains with the most pronounced antagonistic properties are certified and deposited in the collection of microorganisms of the All-Russian State Scientific-Research Consortium of Standardization, Control and Certification.

Due to the increase in the temperature of the permafrost surface layer by $2-4^{\circ} \mathrm{C}$ (in 1900-1980) and the expected further increase by $3^{\circ} \mathrm{C}$, monitoring of permafrost conditions in all disadvantaged settlements on anthrax will be justified [1]. It is known that global warming contributes to the viruses to overcome the interspecific barrier and their spread from warm countries to other territories [2]. The revival of a giant virus from ice with an age of 30 thousand years is an interesting fact. The selection by Yakut scientists of viable bacteria of the genus Bacillus from representatives of the mammoth fauna preserved in perennial frozen soils (age of 3040 thousand years) proves the role of permafrost in preserving bacteria of the Pleistocene period $[3,4]$.

In Russia, the last outbreak of anthrax was observed in Yamal 2016, the cause of which is considered to be thawing of permafrost. Prior to this, an outbreak of anthrax in Yamal was registered in 
1941. Based on this, it can be assumed that spores remained viable in permafrost soil for at least 75 years. The emergence of an infectious disease in Yamal in 2016 was promoted by the abolition of reindeer vaccination in 2007 in view of the recognition in 1968 of this territory free of anthrax [5].

Since 1993, anthrax has not been registered in Yakutia. However, in 2015, 3 strains of the anthrax pathogen were identified as a result of paleontological excavations in the Abyisky district. According to the results of our research in the Abyisky district of Yakutia there are no recorded data on the presence of disadvantaged settlements, which indicates a still insufficient awareness.

It should be noted the lack of scientific data on the survival of the causative agent of anthrax in permafrost conditions. The possibility of the occurrence of anthrax dictates the need to study the survival rate of anthrax pathogen spores in permafrost conditions and the development of means and methods of disinfection.

Thus, knowledge of the timing of the survival of microorganisms at environmental objects in the extreme conditions of the Far North is necessary and helps to optimize ant epizootic and epidemiological measures in the prevention or elimination of infectious diseases in humans and animals.

\section{Acknowledgement}

None.

\section{Conflict of Interest}

No conflict of interest.

\section{References}

1. Revich BA, Podolnaya MA (2011) Thawing of permafrost may disturb historic cabble burial grounds. in Fast Siberia. Global Health Action 4: 8482 .

2. Legendre M, Bartoli J, Shmakova L, Jeudy S, Labadie K, et al. (2014) Thirty-Thousand-year-old distant relative of giant icosahedral DNA viruses with a pandoravirus morphology. Proceeding of the National Academy of Sciences of the United States of America 111(11): 42744279.

3. Neustroev MP (2012) On the prospects of microbiological research on mammoth fauna in permafrost. Quaternary International 255: 139-140.

4. Tarabukina NP, Neustroev MP, Fedorova MP, Parnikova SI, Neustroev MM (2010) Yakutia Zoolite Microflora. In $V^{\text {th }}$ International Cjnference on Mammoth and their Relatives, Pp. 59-60.

5. Timofeev V, Bakhteeva I, Mironova R, Tibareva G, Lev I, et al. (2019) Insigts from Bacillus anthracis isolation from permafrost in the tundra zone of Russia, PLoS One 14(5): e0209140. 